\title{
PENGARUH MODAL USAHA, ORIENTASI PASAR, DAN ORIENTASI KEWIRAUSAHAAN TERHADAP KINERJA UKM KOTA MAKASSAR
}

\author{
DJAMILA ABBAS* \\ Fakultas Ekonomi, Universitas Muhammadiyah Maluku Utara
}

\begin{abstract}
The performance of MSMEs in general varies considerably from year to year. The role of micro, small and medium enterprises (MSMEs) in the Indonesian economy is demonstrated by its population as the largest business drivers, as well as its contribution in employment, the formation of gross domestic product (GDP), exports and the creation of fixed capital / investment. This study assesses whether business capital, market orientation, and entrepreneurship orientation affect the performance of SMEs Makassar City. The total population was 123 businesses of SMEs in Makassar. Data was then regressed to obtain the findings. The results of this study are that there is positive influence of the three variables on the performance of SMEs of Makassar City simultaneously, and partially.
\end{abstract}

Keywords: Performance of SMEs, Capital, Market Orientation, and Orientation of Entrepreneurship

*Surel Korespondensi Penulis: djamilaabbas129@gmail.com

ISSN-E: 2597-6990

ISSN-P: 2442-4951

http://journal.uin-alauddin.ac.id/index.php/minds 


\section{PENDAHULUAN}

Pengembangan Usaha Mikro dan Kecil (UMK) di Indonesia merupakan salah satu prioritas dalam pembangunan ekonomi nasional. Hal ini selain karena usaha tersebut merupakan tulang punggung sistem ekonomi kerakyatan yang tidak hanya ditujukan untuk mengurangi masalah kesenjangan antar golongan, pendapatan dan antar pelaku usaha, ataupun pengentasan kemiskinan dan penyerapan tenaga kerja. Lebih dari itu, pengembangannya mampu memperluas basis ekonomi dan dapat memberikan konstribusi yang signifikan dalam mempercepat perubahan struktural, yaitu meningkatnya perekonomian daerah dan ketahanan ekonomi nasional. Peran usaha mikro, kecil, dan menengah (UMKM) dalam perekonomian Indonesia ditunjukkan oleh populasinya sebagai pelaku usaha terbesar, serta kontribusinya dalam penyerapan tenaga kerja, pembentukan produk domestik bruto (PDB), ekspor dan penciptaan modal tetap/investasi (Tabel 1). Ditinjau secara sektoral, sebagian besar UMKM bergerak di sektor primer (50,1 persen), dan sektor tersier (42,5 persen), dan sebagian kecil di sektor sekunder.

Tabel 1. Perkembangan UMKM Tahun 2010-2012

\begin{tabular}{|c|c|c|c|c|c|c|c|c|}
\hline \multirow[t]{2}{*}{ INDIKATOR } & \multicolumn{3}{|c|}{ DATA } & \multicolumn{2}{|c|}{ PERKEMBANGAN } & \multicolumn{3}{|c|}{ PROPORSI } \\
\hline & 2010 & 2011 & 2012 & $\begin{array}{c}2010 \\
\text { S/D } \\
2011\end{array}$ & $\begin{array}{l}2011 \\
\text { S/D } \\
2012\end{array}$ & 2010 & 2011 & 2012 \\
\hline $\begin{array}{l}\text { Jumlah Unit } \\
\text { Usaha }\end{array}$ & 53,82 Juta & 55,21 Juta & $\begin{array}{r}56,53 \\
\text { Juta } \\
\end{array}$ & $2,57 \%$ & $2,41 \%$ & $99,99 \%$ & $99,99 \%$ & $99,99 \%$ \\
\hline Tenaga Kerja & 99,40 Juta & $\begin{array}{r}101,72 \\
\text { Juta } \\
\end{array}$ & $\begin{array}{r}107,65 \\
\text { Juta } \\
\end{array}$ & $2,33 \%$ & $5,83 \%$ & $97,22 \%$ & $97,24 \%$ & $97,16 \%$ \\
\hline $\begin{array}{l}\text { PDH (Harga } \\
\text { Konstan Th } \\
\text { 2000) }\end{array}$ & $\begin{array}{r}1.282,57 \\
\text { Triliun }\end{array}$ & $\begin{array}{r}1.369,33 \\
\text { Triliun }\end{array}$ & $\begin{array}{r}1.504,93 \\
\text { Triliun }\end{array}$ & $6,76 \%$ & $9,90 \%$ & $57,83 \%$ & $57,60 \%$ & $57,49 \%$ \\
\hline $\begin{array}{l}\text { PDB (Harga } \\
\text { Berlaku) }\end{array}$ & $\begin{array}{r}3.466,39 \\
\text { Triliun } \\
\end{array}$ & $\begin{array}{r}4.303,57 \\
\text { Triliun } \\
\end{array}$ & $\begin{array}{r}4.869,57 \\
\text { Triliun } \\
\end{array}$ & $24,15 \%$ & $13,15 \%$ & $57,12 \%$ & $57,94 \%$ & $59,08 \%$ \\
\hline $\begin{array}{l}\text { Ekspor Non } \\
\text { Migas }\end{array}$ & $\begin{array}{l}157,89 \\
\text { Triliun }\end{array}$ & $\begin{array}{l}187,44 \\
\text { Triliun }\end{array}$ & $\begin{array}{l}208,07 \\
\text { Triliun }\end{array}$ & $6,56 \%$ & $11,00 \%$ & $15,81 \%$ & $16,44 \%$ & $14,06 \%$ \\
\hline $\begin{array}{l}\text { Investasi } \\
\text { (Harga } \\
\text { Konstan Th } \\
\text { 2000) } \\
\end{array}$ & $\begin{array}{l}247,12 \\
\text { Triliun }\end{array}$ & $\begin{array}{l}260,93 \\
\text { Triliun }\end{array}$ & $\begin{array}{l}300,18 \\
\text { Triliun }\end{array}$ & $5,58 \%$ & $15,04 \%$ & $48,34 \%$ & $49,11 \%$ & $51,45 \%$ \\
\hline $\begin{array}{l}\text { Produktivitas } \\
\text { - Per Unit } \\
\text { Usaha } \\
\text { - Per Tenaga } \\
\text { Kerja } \\
\end{array}$ & $\begin{array}{l}\text { 23,83 Juta } \\
\text { 12,90 Juta }\end{array}$ & $\begin{array}{l}24,80 \text { Juta } \\
13,46 \text { Juta }\end{array}$ & $\begin{array}{r}26,62 \\
\text { Juta } \\
13,98 \\
\text { Juta } \\
\end{array}$ & $\begin{array}{l}4,09 \% \\
4,33 \%\end{array}$ & $\begin{array}{l}7,32 \% \\
3,84 \%\end{array}$ & - & - & - \\
\hline
\end{tabular}

Sumber: BPS dan Kementerian Koperasi dan UKM (2011-2013)

Terlepas dari produktivitas yang rendah, UMKM memiliki daya tahan yang lebih baik terhadap krisis, yang terbentuk karena struktur organisasi dan tenaga kerja UMKM yang lebih fleksibel dalam menyesuaikan dengan perubahan pasar. Daya tahan dan fleksibilitas ini menjadikan UMKM digunakan oleh sebagian besar masyarakat sebagai sumber utama penghidupan. Berdasarkan tingkat produktivitas dan kebutuhan untuk meningkatkan populasi usaha kecil dan menengah, maka peningkatan produktivitas usaha mikro dijadikan sebagai target pemberdayaan UMKM ke depan. Perbaikan kapasitas dan produktivitas usaha mikro dapat dilakukan melalui penguatan aset, keterampilan dan keterhubungannya dengan jaringan usaha dan pemasaran dalam satu sistem bisnis yang mapan. Peningkatan kapasitas usaha mikro juga diharapkan dapat meningkatan pendapatan 
masyarakat secara umum yang selanjutnya akan berkontribusi pada pengurangan angka kemiskinan. Peran usaha kecil dan menengah juga perlu ditingkatkan dalam memperkuat basis produksi di dalam negeri, dan partisipasi di pasar ekspor dan investasi. Masalah klasik yang sampai sekarang ini masih belum dapat terselesaikan adalah ketiadaan modal dari sebagian besar UMKM sebagai akibat dari rendahnya akses UMKM terhadap sumbersumber permodalan/pembiayaan terutama perbankan. Pengertian Modal Kerja merupakan investasi dalam harta jangka pendek atau investasi dalam harta lancar (current assets). Modal kerja dapat dikategorikan menjadi dua yaitu modal kerja kotor (gross working capital) dan modal kerja bersih (net working capital). Modal kerja kotor adalah jumlah harta lancar, dan modal kerja bersih adalah jumlah harta lancar dikurangi jumlah utang lancar (current liabilities). Modal kerja adalah jumlah harta lancar yang merupakan bagian dari investasi yang bersirkulasi dari satu bentuk ke bentuk yang lain dalam suatu kegiatan bisnis (Gitman, Juchau, \& Flanagan, 2015). Weston dan Brigham (1986) berpendapat berbeda, bahwa manajemen modal kerja adalah investasi perusahaan dalam jangka pendek: kas, surat-surat berharga (efek), piutang, dan persediaan.

Kinerja perusahaan juga dapat dinilai dari keberhasilan dalam mengelola penjualan, dengan melakukan identitikasi kebutuhan dan keinginan konsumennya melalui penciptaan costumer value dan costumer satisfaction. Dalam mewujudkan tujuan tersebut perusahaan harus mampu mengembangkan strategi pemasaran yang 'market oriented', sehingga perusahaan mampu bersaing dalam meraih pasar yang semakin mengglobal dengan produk-produk import.

Selain itu, berbagai studi menunjukkan bahwa usaha kecil yang 'entrepreneurship oriented' akan menempatkan kemampuan SDM sebagai target yang harus di capai (Agarwal, Audretsch \& Sarkar, 2008; Drucker, 1985:21 \& 35). Dengan mengarahkan berbagai sumber daya yang dimiliki untuk menggunakan sumber daya untuk pencapaian tujuan, maka diharapkan tercipta inovasi dan kreatifitas sehingga menghasilkan kinerja perusahaan menjadi lebih baik. Berdasarkan uraian diatas maka studi ini mengangkat permasalahan tersebut untuk dilakukan penelitian dengan judul Pengaruh Modal Usaha, Orientasi Pasar, dan Orientasi Kewirausahaan Terhadap Kinerja UKM Kota Makassar .

\section{TINJAUAN TEORITIS}

Pengertian Usaha Kecil Menengah

UKM adalah kumpulan perusahaan, yang heterogen dalam ukuran dan sifat, dimana apabila dipergunakan secara bersama akan mempunyai partisipasi langsung dan tidak langsung yang signifikan dalam produksi nasional, penyerapan tenaga kerja dan penciptaan lapangan kerja (Kuwayama, 2001). Usaha Kecil Menengah (UKM) merupakan sebuah istilah yang mengacu pada usaha berskala kecil yang memiliki kekayaan bersih maksimal sekitar Rp 200.000.000, belum termasuk tanah dan bangunan. 
Pengertian Modal Kerja

Modal kerja merupakan investasi dalam harta jangka pendek atau investasi dalam harta lancar (current assets). Modal kerja dapat dikategorikan menjadi dua yaitu modal kerja kotor (gross working capital) dan modal kerja bersih (net working capital). Modal kerja kotor adalah jumlah harta lancar, dan modal kerja bersih adalah jumlah harta lancar dikurangi jumlah utang lancar (current liabilities). Manajemen modal kerja mengelola harta lancar dan utang lancar agar harta lancar selalu lebih besar daripada utang lancar (Gitman, Juchau, \& Flanagan, 2015) menjelaskan bahwa modal kerja adalah jumlah harta lancar yang merupakan bagian dari investasi yang bersirkulasi dari satu bentuk ke bentuk yang lain dalam suatu kegiatan bisnis. Weston dan Brigham (1986) menjelaskan bahwa manjemen modal kerja adalah investasi perusahaan dalam jangka pendek; kas, surat-surat berharga (efek), piutang, dan persediaan. Weston dan Copeland (1997: 239) memberikan pengertian modal kerja sebagai berikut:

"Working capital is defined as current assets minus current liabilities. Thus, working capital represents the firm's investment in cash, marketable securities, accounts receivable, and inventories less the current liabilities used to finance the current assets."

Dari pengertian diatas dapat disimpulkan bahwa modal kerja adalah selisih antara aktiva lancar dan hutang lancar. Dengan demikian modal kerja merupakan investasi dalam kas, surat-surat berharga, piutang dan persediaan dikurangi hutang lancar yang digunakan untuk melindungi aktiva lancar.

Orientasi Pasar

Orientasi pasar merupakan faktor penting yang dapat mempengaruhi kinerja perusahaan Jaworski dan Kohli (1993). Perusahaan yang berorientasi pasar senantiasa menggunakan informasi pasar untuk memenuhi kebutuhan pelanggan pada saat ini maupun prediksi/antisipasi kebutuhan dimasa depan. Kecepatan mengakses informasi pasar dan merespon informasi pasar terkait dengan kemampuan adaptif perusahaan. Narver dan Slater (1990) mendefinisikan orientasi pasar sebagai budaya organisasi yang paling efektif dan efisien untuk menciptakan perilaku-perilaku yang dapat menghasilkan suatu yang terbaik bagi pembeli serta menghasilkan kinerja yang superior bagi perusahaan. Craven (2004) mendefinisikan orientasi pasar sebagai penetapan sasaran konsumen strategis dan membangun organisasi yang berfokus pada layanan konsumen, memberikan dasar persaingan yang berfokus ke dalam, memberi layanan yang sesuai dengan harapan para konsumen, sehingga berhasil memenangkan suatu persaingan. Berdasarkan dua definisi orientasi pasar tersebut dapat disimpulkan bahwa orientasi pasar adalah cara yang dilakukan organisasi untuk mengidentifikasi pasar dan menggunakannya sebagai dasar untuk menentukan strategi perusahaan. Perusahaan-perusahaan yang berhasil dalam mengendalikan pasar disebut sebagai market drive firm, yaitu perusahaan yang selalu menempatkan orientasi pelanggan dan orientasi pesaing secara harmonis, sehingga menghasilkan kinerja pemasaran yang lebih baik (Alam, 2013). Oleh karena itu, konsep utama dalam orientasi pasar adalah orientasi pelangan dan orientasi pesaing. 


\section{Pengertian Kinerja Perusahaan}

Kinerja merujuk pada tingkat pencapaian ataupun prestasi dari perusahaan dalam periode waktu tertentu. Menurut Chandler dan Hanks, (1993) terdapat 2 jenis pendekatan dalam mengukur kinerja, yaitu: Secara obyektif dan secara subyektif. Secara obyektif yaitu jenis pendekatan dengan menggunakan data-data berupa data akuntansi keuangan. Sedangkan secara subyektif yaitu pendekatan untuk mengukur kinerja perusahaan berdasarkan pada persepsi dari para manajer terhadap kinerja perusahaan. Namun menurut sapienza et al. (1988), terdapat kendala/kekurangan jenis pendekatan secara obyektif yaitu: (1) cenderung ada manipulasi angka di pihak manajemen, (2) manajer/pemilik keberatan untuk memberikan informasi dan data-data keuangan (kondisi ini lazim ditemui pada penelitian terhadap perusahaanperusahaan kecil). Untuk itu, Beal (2000) dan Covin (1991) menyatakan bahwa untuk mengantisipasi tidak tersedianya data-data kinerja perusahaan secara obyektif dalam sebuah penelitian, dimungkinkan untuk menggunakan ukuran kinerja secara subyektif yang didasarkan pada persepsi manajer. Jauch dan glueck (1988) mengemukakan bahwa kinerja merujuk pada tingkat pencapaian prestasi dari perusahaan dalam periode waktu tertentu. Kinerja perusahaan adalah hal yang sangat menentukan dalam berkembangnya perusahaan. Di sisi lain, kinerja suatu bisnis merupakan hasil-hasil fungsi pekerjaan kelompok dalam suatu organisasi yang dipengaruhi oleh berbagai faktor untuk mencapai tujuan organisasi dalam periode tertentu.

\section{Hipotesis}

1. Modal Usaha, Orientasi Pasar dan Orientasi Kewirausahaan

Modal usaha mutlak diperlukan untuk melakukan kegiatan usaha. Oleh karena itu diperlukan sejumlah dana sebagai dasar ukuran finasial atas usaha yang dijalankan. Sumber modal usaha dapat diperoleh dari modal sendiri, bantuan pemerintah, lembaga keuangan baik bank dan lembaga keuangan non-bank. Modal adalah faktor usaha yang harus tersedia sebelum melakukan kegiatan. Besar kecilnya modal akan mempengaruhi perkembangan usaha dalam pencapaian pendapatan (Riyanto, 2001), arti modal yang lain, meliputi baik modal dalam bentuk uang maupun dalam bentuk barang. Schwiedlan dalam (Riyanto, 2001) juga mengatakan, modal sangat penting dalam mendirikan sebuah usaha. Adapun orientasi pasar juga merupakan komponen yang sangat penting dalam upaya pengembangan usaha. Tanpa adanya orientasi pasar, suatu usaha akan sulit untuk dapat bersaing dengan perusahaan lain. Selain itu, orientasi kewirausahaan merupakan komponen yang sangat penting dalam mengembangkan usaha.

Orientasi kewirausahaan yang tercermin dari need for achievement, internal locus of control, self reliance, extroversion diyakini mampu mendongkrak kinerja perusahaan. Hal tersebut dikuatkan oleh Covin dan Slevin (1991) yang menyatakan bahwa orientasi kewirausahaan yang semakin tinggi dapat meningkatkan kemampuan perusahaan dalam memasarkan produknya menuju kinerja usaha yang lebih baik, karenanya:

H1 = Terdapat pengaruh modal kerja, orientasi pasar, dan orientasi kewirausahaan terhadap kinerja UKM Kota Makassar. 
2. Modal Usaha Dan Kinerja Perusahaan

Modal kerja adalah jumlah harta lancar yang merupakan bagian dari investasi yang bersirkulasi dari satu bentuk ke bentuk yang lain dalam suatu kegiatan bisnis (Gitman, 2001). Weston dan Brigham (1986) juga menjelaskan bahwa manajemen modal kerja adalah investasi perusahaan dalam jangka pendek: kas, surat-surat berharga (efek), piutang, dan persediaan. Adapun Penelitian terdahulu yang dilakukan oleh Purwanti (2012) menunjukkan pengaruh signifikan antara modal usaha terhadap kinerja perusahaan didalam elemen modal usaha seperti modal syarat untuk usaha, besarnya modal, hambatan sumber modal, dan sumber modal dari luar, karenanya:

H2 = Terdapat pengaruh modal kerja terhadap kinerja UKM Kota Makassar

3. Orientasi Pasar Dan Kinerja Perusahaan

Jaworski dan Kohli (1993) seperti dikutip Adinoto (2013) menyatakan bahwa, orientasi pasar merupakan faktor penting yang dapat mempengaruhi kinerja perusahaan. Perusahaan yang berorientasi pasar senantiasa menggunakan informasi pasar untuk memenuhi kebutuhan pelanggan pada saat ini maupun prediksi/antisipasi kebutuhan dimasa depan. Kecepatan mengakses informasi pasar dan merespon informasi pasar terkait dengan kemampuan adaptif perusahaan. Hal ini juga didukung oleh penelitian Setiawan (2012) yang menyatakan bahwa ada pengaruh signifikan antara orientasi pasar dengan kinerja perusahaan, oleh karena itu:

H3= Terdapat pengaruh orientasi pasar terhadap kinerja UKM Kota Makassar

4. Orientasi Kewirausahaan Dan Kinerja Perusahaan

Orientasi kewirausahaan dapat ditentukan berdasarkan pada empat dimensi yaitu need for achievement, internal locus of control, self reliance dan extroversion (Lee dan Tsang, 2001), sedangkan Wiklund (1999) menyatakan bahwa orientasi kewirausahaan yang semakin tinggi dapat meningkatkan kemampuan perusahaan dalam memasarkan produknya menuju kinerja usaha yang lebih baik. Penelitian terdahulu yang dilakukan oleh Andwiani (2013) menunjukkan pengaruh signifikan antara orientasi kewirausahaan terhadap kinerja perusahaan. Dan dalam penelitian Baum et al. (2001) menyatakan bahwa kewirausahaan berperanguh langsung terhadap kinerja usaha didalam elemen kewirausahaan seperti internal locus, need for echievment, extroversion, education experience dan self reliance mempengaruhi pertumbuhan usaha, karenanya:

H4= Terdapat pengaruh orientasi kewirausahaan terhadap kinerja UKM Kota Makassar

Kerangka Konseptual

Kerangka pikir berikut menjelaskan bahwa variabel modal usah (X_1), orientasi pasar (X_2), dan orientasi kewirausahaan (X_3), merupakan variabel independen/ variabel bebas yang mempengaruhi variabel dependen/terikat. Dimana kinerja ukm kota Makassar (Y) merupakan variabel dependen/ variabel terikat. 


\section{Gambar 1. Kerangka Konseptual}

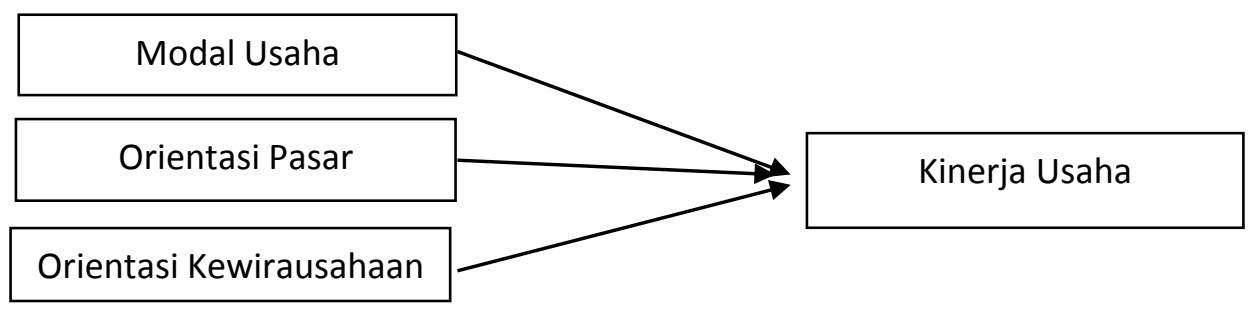

\section{METODE PENELITIAN}

Jenis penelitian yang digunakan adalah metode kuantitatif, yaitu suatu konsep/ide diukur dengan menggunakan teknik yang menghasilkan angkaangka (Jonker et al, 2011: 3). Angka ini yang dianggap mewakili konsep/ide kemudian dianalisis. Adapun populasi dalam penelitian ini adalah UKM kota Makassar yang bergerak di bidang usaha kuliner (makanan/minuman) yang terdaftar di Dinas Koperasi dan UMKM Kota Makassar tahun 2014. Dengan jumlah populasi sebanyak 84 UKM yang terdaftar pada tahun 2014.

Arikunto (2013: 174) berpendapat bahwa sampel adalah sebagian atau wakil populasi yang diteliti. Sedangkan menurut Sugiyono (2013: 118) sampel adalah bagian dari jumlah dan karakteristik yang dimiliki oleh populasi tersebut. Pada penelitian ini obyek yang akan di teliti yaitu UKM bidang kuliner (makanan dan minuman). Dengan alasan karena populasinya di bawah 100, sesuai dengan pendapat Arikunto yaitu apabila populasi kurang dari 100 maka sampel di ambil dari keseluruhan populasi yang ada sehingga disebut penelitian populasi.

Data dikumpulkan melalui penyebaran angket/kuesioner, maupun dokumendokumen terkait lainnya. Pertanyaan kuesioner berupa closed questions dengan pilihan-pilihan jawaban berdasarkan aturan skala Likert 5 poin. Seluruh jawaban akan ditabulasikan untuk kemudian diolah berdasarkan urutanurutan tertentu.

Tahap pertama urutannya adalah melakukan uji validasi dan reliabilitas data, pengujian asumsi klasik, dan yang terakhir analisis regresi berganda. Analisis regresi untuk mengetahui arah hubungan antara variabel independen dengan variabel dependen apakah masing-masing variabel independen berhubungan positif atau negatif dan untuk memprediksi nilai dari variabel dependen apabila nilai variabel independen mengalami kenaikan atau penurunan. Data yang digunakan biasanya berskala interval atau rasio.Persamaan regresi berganda sebagai berikut:

$\mathrm{Y}^{\prime}=\mathrm{a}+\mathrm{b} 1 \mathrm{X} 1+\mathrm{b} 2 \mathrm{X} 2+\mathrm{b} 3 \mathrm{X} 3+\mathrm{e}$

Keterangan:

$\mathrm{Y}^{\prime} \quad=$ Kinerja UKM Kota Makassar

$\mathrm{X} 1=$ Modal Usaha

$\mathrm{X} 2=$ Orientasi Pasar

X3 = Orientasi Kewirausahaan

a $\quad=$ Konstanta (nilai $Y^{\prime}$ apabila $X 1, X 2 \ldots . . X n=0$ )

$\mathrm{b} \quad=$ Koefisien regresi (nilai peningkatan ataupun penurunan) 
hipotesis akan diuji pada skala kebenaran 5\% dengan menggunakan uji t dan uji f pada analisis regresi di atas.

\section{HASIL DAN PEMBAHASAN}

Hasil

Hasil uji validitas dan reliabilitas menunjukkan instrumen kuesioner yang diajukan dalam penelitian ini melalui berbagai item kuesioner adalah valid dan reliabel. Pengujian hubungan dalam uji asumsi klasik, yaitu: uji normalitas data, multikolinearitas, heterokedastisitas, dan autokorelasi menunjukkan keseluruhan instrument kuesioner telah memenuhi syarat untuk dilakukan pengujian hipotesis melalui regresi (selengkapnya lihat lampiran).

Adapun rangkuman hasil regresi untuk pengujian hipotesis adalah sebagai berikut:

Tabel 2, Rangkuman hasil olah data

\begin{tabular}{|c|c|c|c|c|c|c|c|}
\hline \multirow{2}{*}{\multicolumn{2}{|c|}{ Model }} & & \multicolumn{2}{|c|}{$\begin{array}{l}\text { Unstandardized } \\
\text { Coefficients }\end{array}$} & \multicolumn{3}{|c|}{$\begin{array}{c}\text { Standardized } \\
\text { Coefficients }\end{array}$} \\
\hline & & & B & Std. Error & Beta & $\mathrm{t}$ & Sig. \\
\hline \multirow[t]{8}{*}{1} & \multirow{2}{*}{\multicolumn{2}{|c|}{$\begin{array}{l}\text { (Constant) } \\
\text { Modal Usaha }\end{array}$}} & 18.687 & 3.698 & & 5.065 & .000 \\
\hline & & & .619 & .084 & .619 & 7.360 & .000 \\
\hline & \multicolumn{2}{|c|}{ Orientasi Pasar } & .397 & .053 & .268 & 3.451 & .001 \\
\hline & \multicolumn{2}{|c|}{$\begin{array}{l}\text { Orientasi } \\
\text { Kewirausahaan }\end{array}$} & .479 & .139 & .620 & 5.489 & .000 \\
\hline & $\mathrm{R}$ & \multicolumn{3}{|c|}{$=0,548$} & & & \\
\hline & $\mathrm{R}^{2}$ & \multicolumn{3}{|c|}{$=0,531$} & & & \\
\hline & $\mathrm{F}_{\text {hitung }}$ & \multicolumn{2}{|c|}{$=32.291$} & & & & \\
\hline & Sig & \multicolumn{2}{|c|}{$=0,000$} & & & & \\
\hline
\end{tabular}

Berdasarkan tabel diperoleh angka $\mathrm{R}^{2}$ (R Square) sebesar 0,548 atau (54,8\%). Hal ini menunjukkan bahwa persentase sumbangan modal usaha, orientasi pasar, dan orientasi kewirausahaan terhadap kinerja perusahaan sebesar 54,8\% sedangkan sisanya sebesar $45,2 \%$ dijelaskan oleh variabel lain yang tidak dimasukkan dalam model penelitian ini diantaranya seperti inovasi prosuk, strategic leadership, knowledge management, lingkungan internal dan eksternal perusahaan dan lain-lain.

Berdasarkan hasil output SPSS di atas kita dapat melihat bahwa nilai F hitung > nilai $\mathrm{F}$ tabel $(32,291>2,72)$ dengan tingkat signifikan di bawah 0,05 yaitu 0,005. Berdasarkan cara pengambilan keputusan uji simultan dalam analisis regresi dapat disimpulkan bahwa variabel Modal Usaha (X_1), Orientasi Pasar (X_2), dan Orientasi Kewirausahaan (X_3) jika diuji secara bersama-sama atau serempak berpengaruh signifikan terhadap Kinerja Perusahaan (Y).

Berdasarkan hasil output SPSS di atas kita dapat melihat dimana nilai $t$ hitung variabel (X_1 ) lebih besar dari pada nilai t tabel $(7,360>1,664)$ dengan tingkat signifikan dibawah 0,05 yaitu 0,000, t hitung variabel (X_2 ) lebih besar dari 
pada nilai $\mathrm{t}$ tabel $(3,451>1,664)$ dengan tingkat signifikan dibawah 0,05 yaitu 0,001 dan thitung variabel (X_3 ) lebih besar dari pada nilai t tabel $(5,489>1,664)$ dengan tingkat signifikan dibawah 0,05 yaitu 0,000. Berdasarkan cara pengambilan keputusan uji parsial dalam analisis regresi dapat disimpulkan sebagai berikut:

- Variabel Modal Usaha secara parsial berpengaruh positif terhadap Kinerja Perusahaan.

- Variabel Orientasi Pasar secara parsial berpengaruh positif terhadap Kinerja Perusahaan.

- Variabel Orientasi Kewirausahaan secara parsial berpengaruh positif terhadap Kinerja Perusahaan.

\section{Pembahasan}

1. Pengaruh Modal Usaha, Orientasi, dan Orientasi kewirausahaan terhadap Kinerja Perusahaan.

Berdasarkan hasil analisis variabel modal usaha, orientasi pasar, dan orientasi kewirausahaan berpengaruh positif secara simultan terhadap Kinerja Perusahaan. Dimana Modal usaha ini terdiri dari beberapa indikator yaitu modal syarat untuk usaha, besar modal, hambatan sumber modal, dan sumber modal dari luar. Orientasi Pasar terdiri dari orientasi pelanggan, orientasi pesaing, informasi pasar. Orientasi Kewirausahaan terdiri dari need for achievment, internal locus of control self reliance, dan extroversion. Hasil uji empiris menunjukkan Modal Usaha, Orientasi Pasar, dan Orientasi Kewirausahaan merupakan faktor yang berperan penting yang menentukan tinggi rendahnya peningkatan kinerja perusahaan. Semakin tinggi modal usaha, orientasi pasar, dan orientasi kewirausahaan, akan mendorong semakin tingginya kinerja perusahaan (UKM kota Makassar). Sebaliknya jika modal usaha, orientasi pasar, dan orientasi kewirausahaan rendah, maka kinerja perusahaan juga akan mengalami penurunan. Hasil dari analisis ini menerima hipotesis 1 bahwa Modal Usaha, Orientasi Pasar, dan Orientasi Kewirausahaan, berpengaruh secara simultan terhadap Kinerja Perusahaan.

Hasil penelitian ini sejalan dengan penelitian Saskara (2007) bahwa pertumbuhan ekonomi didukung kebijakan neraca modal yang liberal, baik bagi modal yang masuk maupun yang keluar. Kesuksesan ini menimbulkan suatu optimisme yang luar biasa di satu pihak dan di pihak lain keteledoran yang tidak tanggungtanggung. Suatu optimisme yang mendorong kebijakankebijakan ekonomi dan tingkah laku para pelaku ekonomi dalam dan luar negeri sepertinya lepas kendali. Penelitian ini juga mendukung penemuan yang dikemukakan oleh Jaworski dan Kohli (1993) seperti dikutip Adinoto (2013) menyatakan bahwa, orientasi pasar merupakan faktor penting yang dapat memengaruhi kinerja perusahaan. Perusahaan yang berorientasi pasar senantiasa menggunakan informasi pasar untuk memenuhi kebutuhan pelanggan pada saat ini maupun prediksi/antisipasi kebutuhan di massa depan. Kecepatan mengakses informasi pasar dan merespon informasi pasar terkait dengan kemampuan adaptif perusahaan. Selain itu hasil penelitian Lumpkin dan Dess (1996) menyatakan, bahwa ada 5 dimensi yang mempengaruhi kinerja perusahaan/korporasi yaitu kebebasan, inovasi, 
kesediaan untuk mengambil resiko, proaktif, dan keagresifan bersaing. Lumpkin dan Dess (1996) menyatakan bahwa kunci utama dari dimensi orientasi kewirausahaan adalah meliputi tindakan yang dapat dilakukan secara bebas atau tidak bergantung pada pihak lain, artinya adanya kehendak untuk mengadakan pembaharuan dan bersedia menanggung resiko, cenderung lebih agresif dari pesaing, serta proaktif dalam usaha melihat atau meramalkan dan mengantisipasi peluang yang ada di pasar.

2. Pengaruh modal usaha terhadap kinerja perusahaan

Berdasarkan hasil analisis maka disimpulkan bahwa variabel Modal Usaha berpengaruh positif secara parsial terhadap Kinerja Perusahaan. Dimana modal usaha ini terdiri dari beberapa indikator yaitu modal syarat untuk usaha, besar modal, hambatan sumber modal, dan sumber modal dari luar. Hasil ini mengisyaratkan modal usaha merupakan salah satu faktor yang berperan penting yang menentukan tinggi rendahnya peningkatan kinerja perusahaan. Semakin tinggi modal usaha, akan mendorong semakin tingginya kinerja perusahaan (UKM kota Makassar). Sebaliknya jika modal usaha rendah, maka kinerja perusahaan juga akan mengalami penurunan. Hasil dari analisis ini menerima hipotesis 2 bahwa Modal Usaha berpengaruh terhadap Kinerja Perusahaan.

Penelitian ini mendukung penelitian Purwanti (2012), dengan hasil penelitian yang menunjukan ada pengaruh yang positif dan signifikan faktor modal usaha terhadap perkembangan usaha UMKM di desa Dayaan dan desa Kalilondo di Salatiga . Modal usaha yang dimaksud adalah modal usaha yang digunakan dalam menunjang usaha dan kemudahan mendapatkan modal usaha. Semakin besar modal yang digunakan dan semakin mudah untuk mendapatkan modal usaha akan mengakibatkan meningkatnya perkembangan usaha.

3. Pengaruh Orientasi Pasar terhadap Kinerja Perusahaan

Berdasarkan hasil analisis variabel Orientasi Pasar berpengaruh positif secara parsial terhadap Kinerja Perusahaan. Dimana orientasi pasar ini terdiri dari beberapa indikator yaitu orientasi pelanggan, orientasi pesaing, informasi pasar. Narver dan Slater (1990) mendefinisikan orientasi pasar sebagai budaya organisasi yang paling efektif dan efisien untuk menciptakan perilaku-perilaku yang dapat menghasilkan suatu yang terbaik bagi pembeli serta menghasilkan kinerja yang superior bagi perusahaan. Semakin tinggi orientasi pasar akan mendorong semakin tingginya kinerja perusahaan (UKM) di kota Makassar. Sebaliknya jika orientasi pasar rendah kinerja perusahaan (UKM) juga akan mengalami penurunan. Hasil dari analisis ini menerima hipotesi bahwa Inovasi Kewirausahaan berpengaruh terhadap Kinerja Perusahaan.

Dengan demikian penelitian ini mendukung hasil penelitiannya Han et al. (1998), zhou et al. (2005), dalam penelitiannya menyimpulkan bahwa orientasi pasar berpengaruh signifikan terhadap Kinerja perusahaan. Temuan ini didukung oleh Kumar, Subramanian dan Strandholm, (2001) yang menyatakan bahwa orientasi pasar berpengaruh signifikan terhadap kinerja perusahaan. Dengan demikian dapat dikatakan bahwa UMKM di Kota Makassar telah melakukan strategi yang berorientasi terhadap pasar walaupun 
tidak urgent namun orientasi pasar ini penting ketika UMKM telah memiliki produk dan usaha yang semakin berkembang, maka perluasan pasar tentu sangat di perlukan.

4. Pengaruh Orientasi Kewirausahan terhadap Kinerja Perusahaan

Berdasarkan hasil analisis, variabel orientasi kewirausahan berpengaruh positif secara parsial terhadap Kinerja Perusahaan. Dimana orientasi kewirausahan ini terdiri dari beberapa indikator yaitu need for achievmen, internal locus of control, self reliance, dan extroversion. Hipotesis empat yang menyatakan bahwa orientasi kewirausahaan berpengaruh signifikan terhadap kinerja usaha UMKM terbukti. Hasil ini mengisyaratkan orientasi kewirausahaan merupakan salah satu faktor yang berperan penting yang menentukan tinggi rendahnya peningkatan kinerja perusahaan. Semakin tinggi orientasi kewirausahaan, akan mendorong semakin tingginya kinerja perusahaan (UKM kota Makassar). Sebaliknya jika orientasi kewirausahaan rendah, maka kinerja perusahaan juga akan mengalami penurunan. Hasil dari analisis ini menerima hipotesis 4 bahwa Orientasi Kewirausahaan berpengaruh terhadap Kinerja Perusahaan.

Temuan ini mendukung hasil penelitian McGrath (1996), menyatakan bahwa orientasi kewirausahaan dapat menjadi suatu cara pengukuran yang paling penting tentang bagaimana sebuah perusahaan di organisir dan merupakan sumbangan kewirausahaan (entrepreneurship) yang penting terhadap kinerja perusahaan. Hal ini juga sejalan dengan pandangan Lee dan Tsang (2001) yang menyatakan bahwa orientasi kewirausahaan berpengaruh terhadap kinerja.Zheng et al (2005) dalam penelitiannya mengatakan bahwa orientasi kewirausahaan memiliki pengaruh positif terhadap kinerja. Hal itu diyakini karena Orientasi Kewirausahaan memainkan peranan yang kursial dalam menjamin suksesnya suatu program bisnis yang dijalankan dan memberikan dukungan dan dorongan melalui sikap wirausaha untuk mencapai kesuksesan dalam berusaha (Hunter dan Rogres. D, 1339:153). Hashim et al (2015) menjelaskan bahwa ada dampak positif orientasi kewirausahaan terhadap kinerja, karena ada hubungan langsung antara orientasi kewirausahaan terhadap kinerja bahwa efek independen dari masingmasing dimensi orientasi kewirausahaan berkontribusi terhadap kinerja dan ada hubungan diverensial inovasi, proaktif dan mengambil resiko pada tujuan kinerja. Sedangkan penelitian Hashim et al (2015) memverifikasi hubungan langsung orientasi kewirausahaan terhadap kinerja, dengan sampel penelitiannya yaitu perusahaan bumi putera dan UKM di 3 negara bagian utara semenanjung Malaysia yaitu penang, kedah, dan perlis

Hasil deskriptif penelitian ini juga menunjukkan bahwa orientasi kewirausahaan di persepsikan cukup baik oleh pemilik usaha (UKM) di Makassar. Oleh karena itu, untuk meningkatkan kinerja UKM hal yang perlu diperhatikan dan ditingkatkan yaitu need for achievement, internal locus of control, self reliance, dan extroversion.

Kesimpulan

Berdasarkan hasil dari seluruh topik di atas maka dapat disimpulkan bahwa, Modal usaha, orientasi pasar, dan orientasi kewirausahaan berpengaruh 
terhadap kinerja UKM Industri Makanan Minuman Kota Makassar. Adapun modal usaha berpengaruh terhadap kinerja UKM Industri Makanan Minuman Kota Makassar. Orientasi pasar juga ditemukan berpengaruh terhadap kinerja UKM Industri Makanan Minuman Kota Makassar. dan Orientasi kewirausahaan berpengaruh terhadap kinerja UKM Industri Makanan Minuman Kota Makassar.

Studi Lanjutan

Penelitian selanjutnya dapat menelaah kembali beberapa topik kinerja perusahaan yang belum dapat dimasukkan, oleh karena itu disarankan bagi peneliti selanjutnya untuk menambah variabel lain seperti inovasi produk, strategic leadership, knowledge managemen, lingkungan internal dan eksternal perusahaan, dan beberapa faktor penentu lain dalam peningkatan kinerja perusahaan sehingga dapat memperkaya pool of knowldedge penelitian tentang ilmu manajemen.

\section{DAFTAR PUSTAKA}

Adinoto, A. (2013). Pengaruh Orientasi Pasar dan Perilaku Kewirausahaan Terhadap Kepekaan Perusahaan Dan Implikasinya Pada Kinerja Perusahaan: Studi pada Penyalur Sepeda Motor di Indonesia. ULTIMA MANAJEMEN, 2(1).

Agarwal, R., Audretsch, D., \& Sarkar, M. B. (2007). The process of creative construction: knowledge spillovers, entrepreneurship, and economic growth.Strategic Entrepreneurship Journal, 1(3-4), 263-286.

Alam, M.M., (2013), Effect of Market Orientation on Small Business Perormance in SmallTown In Malaysia: An Emprical Study on Malaysian Small Firms, Journal of Strategic Marketing, Vol 1, No. 3.

Andwiani Sinarasri. "Analisis Pengaruh Orientasi Kewirausahaan Terhadap Strategi Bisnis Dalam Meningkatkan Kinerja Perusahaan (Studi Kasus Pada Pedagang Kaki Lima Bidang Kuliner Di Semarang)" (Jurnal). Semarang: Universitas Muhammadiyah. 2013.

Arikunto, S. (2013). Prosedur Penulisan Suatu Pendekatan Praktik Cetakan Kelima Belas. Jakarta: Rinerka Cipta.

Baum, J. R., Locke, E. A., \& Smith, K. G. (2001). A multidimensional model of venture growth. Academy of management journal, 44(2), 292-303.

Beal, R. M. (2000). Competing effectively: environmental scanning, competitive strategy, and organizational performance in small manufacturing firms. Journal of small business management, 38(1), 27.

Chandler, G. N., \& Hanks, S. H. (1994). Market attractiveness, resource-based capabilities, venture strategies, and venture performance. Journal of business venturing, 9(4), 331-349.

Covin, J. G. (1991). Entrepreneurial versus conservative firms: A comparison of strategies and performance. Journal of management studies, 28(5), 439462.

Covin, J. G., \& Slevin, D. P. (1991). A conceptual model of entrepreneurship as firm behavior. Entrepreneurship theory and practice, 16(1), 7-26.

Craven, D. W,(2004). Strategic Marketing, Sevent Edition. 
Drucker, P. F. (1985). Entrepreneurial strategies. California Management Review, 27(2), 9-25.

Gitman, L. J., Juchau, R., \& Flanagan, J. (2015). Principles of managerial finance. Pearson Higher Education AU.

Han, J. K., Kim, N., \& Srivastava, R. K. (1998). Market orientation and organizational performance: is innovation a missing link?. The Journal of marketing, 30-45.

Hashim, S. F., Tajuddin, R. M., \& Zainol, A. S. (2015). Creating Resilient SME Through Brand Identity (Case Study of Bumiputera Fashion Entrepreneurs in Malaysia. International Academic Research Journal of Social Science, 1(2), 2015.

Jauch, L. R., \& Glueck, W. F. (1988). Business policy and strategic management. McGraw-Hill.

Jaworski, B. J., \& Kohli, A. K. (1993). Market orientation: antecedents and consequences. The Journal of marketing, 53-70.

Jonker, J., Pennink, B. J. W., \& Wahyuni, S. (2011). Metodologi Penelitian: Panduan untuk Master dan Ph. D. di Bidang Manajemen. Jagakarsa, Jakarta (Indonesia): Penerbit Salemba Empat.

Kumar, K., \& Subramanian, R. (2000). Navigating the external environment through a market orientation. SAM Advanced Management Journal, 65(1), 16.

Kuwayama, M. (2001). E-Commerce and export promotion policies for small and medium-sized enterprises: East Asian and Latin American experiences (Vol. 13). United Nations Publications.

Lee, D. Y., \& Tsang, E. W. (2001). The effects of entrepreneurial personality, background and network activities on venture growth. Journal of management studies, 38(4), 583-602.

Lumpkin, G. T., \& Dess, G. G. (1996). Clarifying the entrepreneurial orientation construct and linking it to performance. Academy of management Review, 21(1), 135-172.

McGrath, R. G. (1996, August). Options and The Enterprise: toward a Strategic Theory of Entrepreneurial Wealth Creation. In Academy of Management Proceedings (Vol. 1996, No. 1, pp. 101-105). Briarcliff Manor, NY 10510: Academy of Management.

Narver, J. C., \& Slater, S. F. (1990). The effect of a market orientation on business profitability. The Journal of marketing, 20-35.

Purwanti, E. (2012). Pengaruh Pangsa Pasar, Rasio Leverage, Intensitas Modal Terhadap Profitabilitas Koperasi Simpan Pinjam di Salatiga. Jurnal Ilmiah Among Makarti, 3(5).

Riyanto, Y. (2001). Metodologi penelitian pendidikan.

Sapienza, H. J., Smith, K. G., \& Gannon, M. J. (1988). Using subjective evaluations of organizational performance in small business research. American Journal of Small Business, 12(3), 45-54.

Saskara, I. N., \& Putra, I. (2013). Efektivitas dan Dampak Program Bantuan Kredit Usaha Rakyat (KUR) terhadap Pendapatan dan Kesempatan Kerja 
Usaha Mikro Kecil dan Menengah (UMKM) di Kota Denpasar. E-Jurnal Ekonomi Pembangunan Universitas Udayana, 2(10).

Setiawan, H. (2012). Pengaruh Orientasi Pasar, Orientasi Teknologi dan Inovasi Produk Terhadap Keunggulan Bersaing Usaha Songket Skala Kecil di Kota Palembang. ORASI BISNIS, 8(2).

Sugiyono, P. D. (2013). Metode Penelitian Manajemen. Bandung: Alfabeta, CV. Weston, F. J dan Thomas, E Copeland. 1997. Manajemen Keuangan: Jilid, 2.

Weston, J. F., \& Brigham, E. F. (1986). Fundamental of Financial Management. Edisi Tujuh.

Wiklund, J. (1999). The sustainability of the entrepreneurial orientationperformance relationship. Entrepreneurship theory and practice, 24(1), 3748.

Zheng, C., \& Khavul, S. (2005). Capability development, learning and growth in international entrepreneurial firms: evidence from China. In International entrepreneurship (pp. 273-296). Emerald Group Publishing Limited.

Zhou, K. Z., Brown, J. R., \& Dev, C. S. (2009). Market orientation, competitive advantage, and performance: A demand-based perspective. Journal of business research, 62(11), 1063-1070.

\section{LAMPIRAN}

Tabel 3 Hasil Uji Validasi Modal Usaha

\begin{tabular}{|c|c|c|c|c|c|}
\hline No & Variabel $\boldsymbol{X}_{\mathbf{1}}$ & Item & r-hitung & r-tabel & Keterangan \\
\hline \multirow{2}{*}{1} & Modal syarat untuk & $\mathrm{P} 1$ & 0,564 & 0,215 & valid \\
\cline { 3 - 6 } & usaha & $\mathrm{P} 2$ & 0,591 & 0,215 & valid \\
\hline \multirow{2}{*}{3} & Besar modal & $\mathrm{P} 1$ & 0,566 & 0,215 & valid \\
\cline { 3 - 6 } & Hambatan sumber & $\mathrm{P} 2$ & 0,621 & 0,215 & valid \\
\cline { 3 - 6 } & P1 & 0,406 & 0,215 & valid \\
\hline 4 & $\begin{array}{c}\text { Sumber modal } \\
\text { luar }\end{array}$ & $\mathrm{P} 1$ & 0,598 & 0,215 & valid \\
\hline
\end{tabular}

Tabel 4 Hasil Uji Validasi Orientasi Pasar

\begin{tabular}{|c|c|c|c|c|c|}
\hline No & Variabel $\boldsymbol{X}_{\mathbf{2}}$ & Item & r-hitung & r-tabel & Keterangan \\
\hline \multirow{3}{*}{1} & Orientasi Pelanggan & P1 & 0,790 & 0,215 & valid \\
\cline { 3 - 6 } & & P2 & 0,722 & 0,215 & valid \\
\hline \multirow{3}{*}{2} & \multirow{3}{*}{ Orientasi Pesaing } & P1 & 0,877 & 0,215 & valid \\
\cline { 3 - 6 } & & P2 & 0,793 & 0,215 & valid \\
\cline { 3 - 6 } & & P3 & 0,665 & 0,215 & valid \\
\hline 3 & Informasi Pasar & P1 & 0,616 & 0,215 & valid \\
\hline
\end{tabular}


Tabel 5 Hasil Uji Validasi Orientasi Kewirausahaan

\begin{tabular}{|c|c|c|c|c|c|}
\hline No & Variabel $\boldsymbol{X}_{\mathbf{3}}$ & Item & r-hitung & r-tabel & Keterangan \\
\hline 1 & Need For Achievement & $\mathrm{P} 1$ & 0,681 & 0,215 & valid \\
\cline { 3 - 6 } & & $\mathrm{P} 2$ & 0,642 & 0,215 & valid \\
\hline 2 & Self Reliance & $\mathrm{P} 1$ & 0,375 & 0,215 & valid \\
\hline \multirow{3}{*}{3} & \multirow{3}{*}{4} & $\mathrm{P} 1$ & 0,810 & 0,215 & valid \\
\cline { 3 - 6 } & \multirow{3}{*}{ Internal locus of control } & $\mathrm{P} 2$ & 0,843 & 0,215 & valid \\
\cline { 3 - 6 } & & $\mathrm{P} 1$ & 0,738 & 0,215 & valid \\
\cline { 3 - 6 } & & $\mathrm{P} 2$ & 0,710 & 0,215 & valid \\
\cline { 3 - 6 } & & $\mathrm{P} 3$ & 0,695 & 0,215 & valid \\
\hline
\end{tabular}

Tabel 6 Hasil Uji Validasi Kinerja Perusahaan

\begin{tabular}{|c|c|c|c|c|c|}
\hline No & Variabel Y & Item & r-hitung & r-tabel & Keterangan \\
\hline \multirow{3}{*}{1} & \multirow{3}{*}{ Kinerja Keuangan } & P1 & 0,691 & 0,215 & valid \\
\hline & & $\mathrm{P} 2$ & 0,657 & 0,215 & valid \\
\hline & & P3 & 0,732 & 0,215 & valid \\
\hline \multirow[t]{2}{*}{2} & \multirow[t]{2}{*}{ Perspektif pelanggan } & P1 & 0,857 & 0,215 & valid \\
\hline & & P2 & 0,795 & 0,215 & valid \\
\hline \multirow[t]{2}{*}{3} & \multirow{2}{*}{$\begin{array}{l}\text { Perspektif Bisnis } \\
\text { Internal }\end{array}$} & P1 & 0,610 & 0,215 & valid \\
\hline & & P2 & 0,662 & 0,215 & valid \\
\hline \multirow[t]{2}{*}{4} & \multirow{2}{*}{$\begin{array}{c}\text { Perspektif } \\
\text { Pertumbuhan dan } \\
\text { pembelajaran }\end{array}$} & P1 & 0,792 & 0,215 & valid \\
\hline & & P2 & 0,849 & 0,215 & valid \\
\hline
\end{tabular}

Gambar 2 Uji Normalitas Data

Normal P-P Plot of Regression Standardized Residual

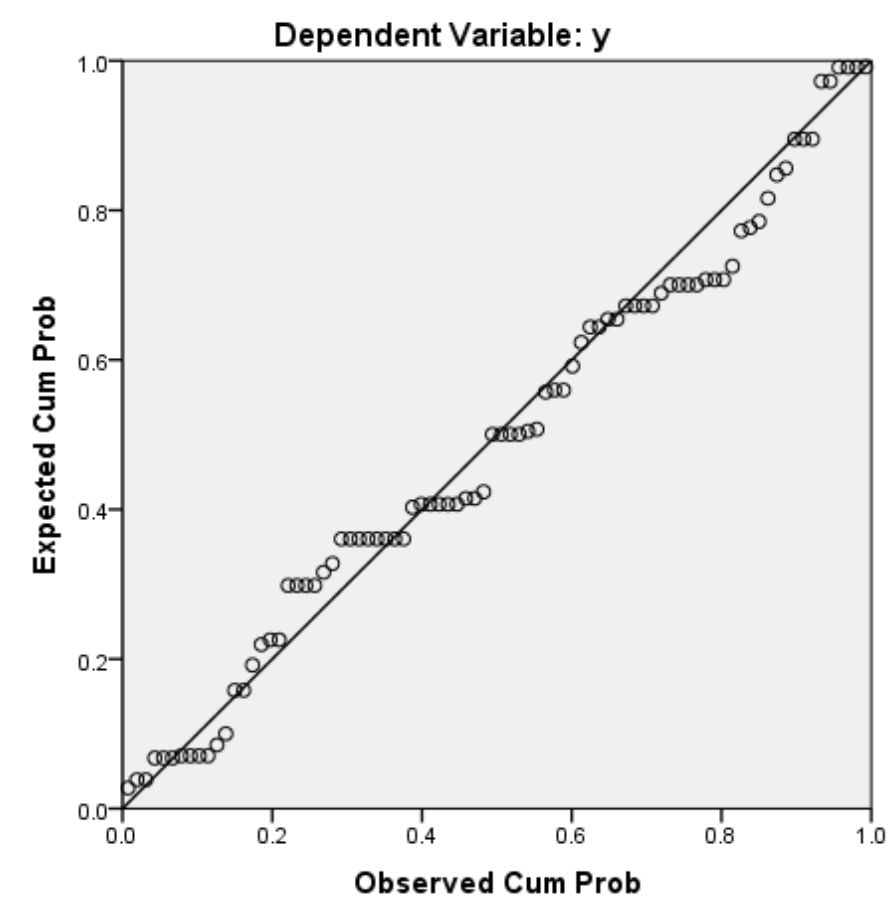

Sumber: Data Primer yang diolah, 2017 
Tabel 7. Uji Autokorelasi

\begin{tabular}{|l|r|r|r|r|r|}
\hline Model & $\mathrm{R}$ & R Square & $\begin{array}{c}\text { Adjusted R } \\
\text { Square }\end{array}$ & $\begin{array}{c}\text { Std. Error of } \\
\text { the Estimate }\end{array}$ & $\begin{array}{c}\text { Durbin- } \\
\text { Watson }\end{array}$ \\
\hline 1 & $.740 \mathrm{a}$ & .548 & .531 & 1.565 & 2.146 \\
\hline
\end{tabular}

a. Predictors: (Constant), OrientasiKewirausahaan, OrientasiPasar, ModalUsaha

b. Dependent Variable: KinerjaPerusahaan

\section{Gambar 3 Hasil Uji Heteroskedestisitas}

Scatterplot

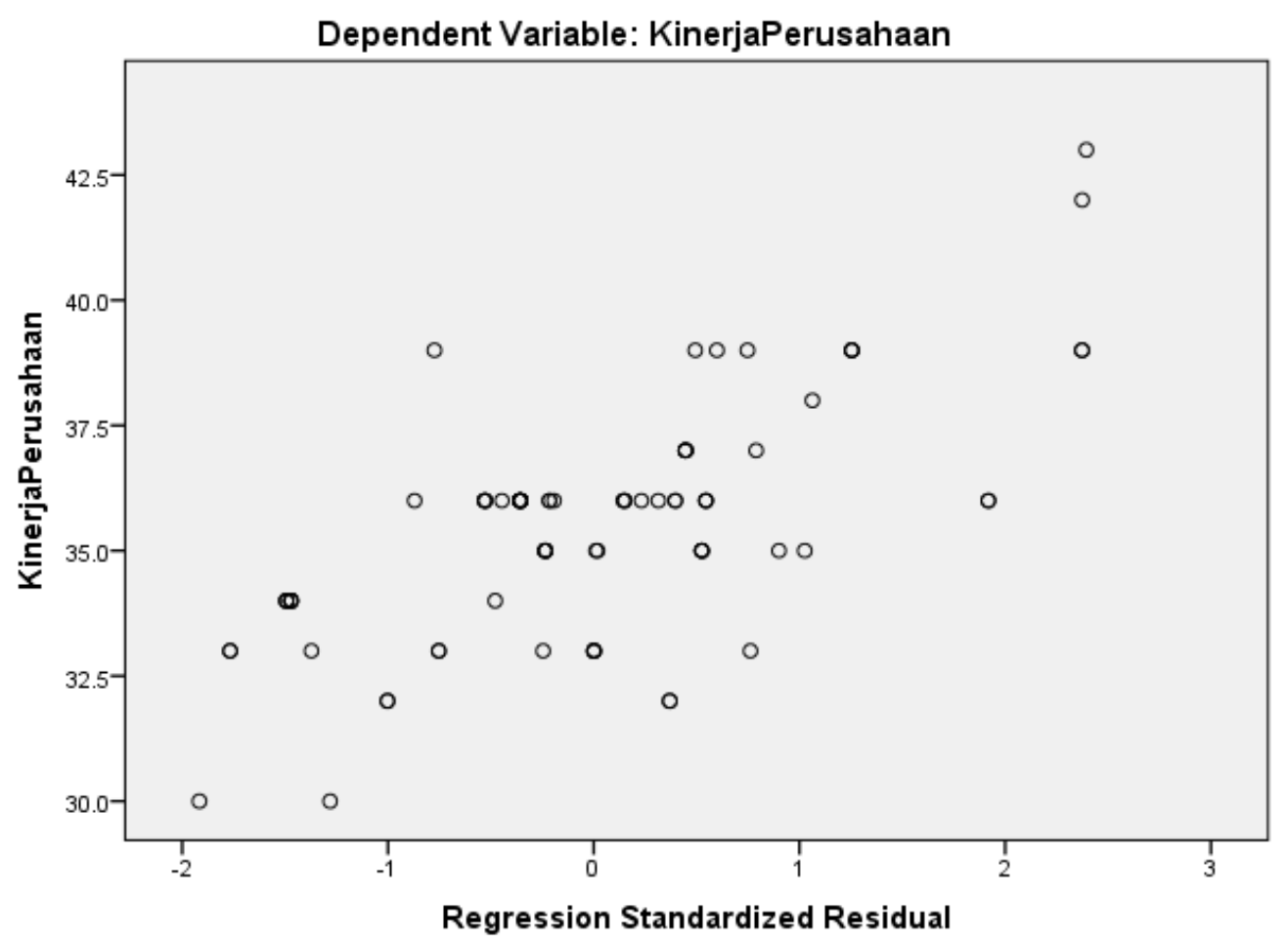

Tabel 8 Uji Multikolineritas

Coefficients ${ }^{\mathrm{a}}$

\begin{tabular}{|c|c|c|c|c|c|c|}
\hline \multirow{2}{*}{\multicolumn{2}{|c|}{ Model }} & \multicolumn{2}{|c|}{$\begin{array}{c}\text { Unstandardized } \\
\text { Coefficients }\end{array}$} & \multirow{2}{*}{$\begin{array}{c}\begin{array}{c}\text { Standardize } \\
\mathrm{d} \\
\text { Coefficients }\end{array} \\
\text { Beta } \\
\end{array}$} & \multicolumn{2}{|c|}{$\begin{array}{l}\text { Collinearity } \\
\text { Statistics }\end{array}$} \\
\hline & & B & $\begin{array}{l}\text { Std. } \\
\text { Error }\end{array}$ & & $\begin{array}{c}\text { Toleranc } \\
\text { e }\end{array}$ & VIF \\
\hline \multirow[t]{4}{*}{1} & (Constant) & 18.687 & 3.689 & & & \\
\hline & ModalUsaha & .619 & .084 & .619 & .800 & 1.250 \\
\hline & OrientasiPasar & .479 & .139 & .268 & .940 & 1.064 \\
\hline & $\begin{array}{l}\text { OrientasiKewirau } \\
\text { sahaan }\end{array}$ & .397 & .053 & .620 & .826 & 1.211 \\
\hline
\end{tabular}

a. Dependent Variable: KinerjaPerusahaan 
Tabel 9. Hasil Uji Regresi Linear Berganda

Coefficients

\begin{tabular}{|c|c|c|c|c|c|c|}
\hline \multirow{2}{*}{\multicolumn{2}{|c|}{ Model }} & \multicolumn{2}{|c|}{$\begin{array}{c}\text { Unstandardized } \\
\text { Coefficients }\end{array}$} & $\begin{array}{l}\text { Standardized } \\
\text { Coefficients }\end{array}$ & \multirow[b]{2}{*}{$\mathrm{t}$} & \multirow[b]{2}{*}{ Sig. } \\
\hline & & B & $\begin{array}{l}\text { Std. } \\
\text { Error }\end{array}$ & Beta & & \\
\hline \multirow[t]{4}{*}{1} & (Constant) & 18.687 & 3.689 & & 5.065 & .000 \\
\hline & ModalUsaha & .619 & .084 & .619 & 7.360 & .000 \\
\hline & OrientasiPasar & .397 & .053 & .268 & 3.451 & .001 \\
\hline & $\begin{array}{l}\text { OrientasiKewirau } \\
\text { sahaan }\end{array}$ & .479 & .139 & .620 & 5.489 & .000 \\
\hline
\end{tabular}

a. Dependent variabel: Kinerja perusahaan

Sumber: Data Diolah (Output SPSS 22.0) 2017

Tabel 10. Hasil Uji Koefisien Determinasi

Model Summaryb

\begin{tabular}{|c|c|c|c|c|c|c|c|c|c|}
\hline \multirow[b]{2}{*}{$\begin{array}{l}\text { Mod } \\
\text { el }\end{array}$} & \multirow[b]{2}{*}{$\mathrm{R}$} & \multirow[b]{2}{*}{$\begin{array}{c}\mathrm{R} \\
\text { Squar } \\
\mathrm{e}\end{array}$} & \multirow[b]{2}{*}{$\begin{array}{c}\text { Adjuste } \\
\text { d R } \\
\text { Square }\end{array}$} & \multirow[b]{2}{*}{$\begin{array}{l}\text { Std. Error } \\
\text { of the } \\
\text { Estimate }\end{array}$} & \multicolumn{5}{|c|}{ Change Statistics } \\
\hline & & & & & $\begin{array}{c}\mathrm{R} \\
\text { Square } \\
\text { Chang } \\
\mathrm{e}\end{array}$ & $\begin{array}{c}\mathrm{F} \\
\text { Change }\end{array}$ & $\begin{array}{c}\mathrm{df} \\
1\end{array}$ & $\begin{array}{c}\mathrm{df} \\
2\end{array}$ & $\begin{array}{l}\text { Sig. F } \\
\text { Chang } \\
\text { e }\end{array}$ \\
\hline 1 & $\begin{array}{r}.740 \\
\mathrm{a}\end{array}$ & .548 & .531 & 1.565 & .548 & 32.291 & 3 & 80 & .000 \\
\hline
\end{tabular}

a. Predictors: (Constant), OrientasiKewirausahaan, OrientasiPasar, ModalUsaha

b. Dependent Variable: KinerjaPerusahaan

Sumber: Data Diolah (Output SPSS 22.0) 2017 